\title{
A VILLAGE OF PALESTINE HERITAGE - AL-DHAHIRIYA PALESTINE
}

\author{
GHASSAN J. DWEIK \\ Palestine Polytechnic University (PPU), Palestine.
}

\begin{abstract}
In 2009, Palestinian historian Bshara Domani identified a popular phenomenon among Palestinians called 'the archive fever'. During the last 40 years many researchers and artists searched through their old pictures and Archival collections; in addition they tried to conduct interviews with the old people and collect data of the old buildings and the demolished villages. Clearly, this is difficult for people who lost their geography, most of their cities, half of their villages and were expelled from their land. These people - the Palestinians - are trying to describe their history which was not allowed to be narrated at the time of Israeli occupation in 1948.

The project of 'documenting and rehabilitating the old centres of the Palestinian villages' aims at exploring the current status of 800 village centres which survived after the 1948 war and which contained an independent, self-sufficient lifestyle. The Palestinian villages endured for centuries using primitive skills that offered a sustainability model developed by the residents. This article is a visual and practical tour in a part of the Palestinian rural area and a clear evidence in the 21 st century on the remaining distinctive architectural heritage that is under threat. It is also an attempt to increase the awareness and finding the right solutions to rehabilitate the Palestinian villages.

For centuries, the architecture in the Palestinian villages was described as 'spontaneous simple architecture', and until the 1920s, the mountains of the West Bank was the heart of rural life in Palestine. Al-Dhahiriya village - the example which is studied in this article - is a small village located in the south of West Bank. The old core of Al-Dhahiriya will be analysed in this article.

Keywords: Al-Dhahiriya village, archaeological, dwelling, environment, Hebron, historic centre, Israeli, Palestine, residential, souk, stone, traditional.
\end{abstract}

\section{THE VILLAGE OF AL-DHAHIRIYA}

Al-Dhahiriya is a Palestinian town in the Hebron Governorate, and is located $23 \mathrm{~km}$ south of the city of Hebron. According to the Palestinian Central Bureau of Statistics, Al-Dhahiriya had a population of 28,776 in 2007. The village is an archaeological site. It has always been the southern gateway to the central highlands of Palestine, and has played a defensive role fending off Bedwouin raids and foreign campaigns. Part of the Roman Fort still stands, and remnants of Hellenistic, Roman and Crusader structures can be found in and around AlDhahiriya. The reuse of antiquity stones in the historic structures is evident of continuous habitation on the hill since ancient times (Fig. 1).

Al-Dhahiriya is known for being a commercial hub that connects Hebron with the Nagev desert. This peripheral location made the village a central market of commerce for surrounding smaller communities as well as for Bedouins residing in the desert. Historically the town hosted a weekly cattle market. The historic marketplace, known as the old souk where buildings still stand, is a 200-meter-long street, that until the late 1970s had shops advertising local merchandise and cattle products, along with a local oven that baked bread for residents and shoppers [1]. 


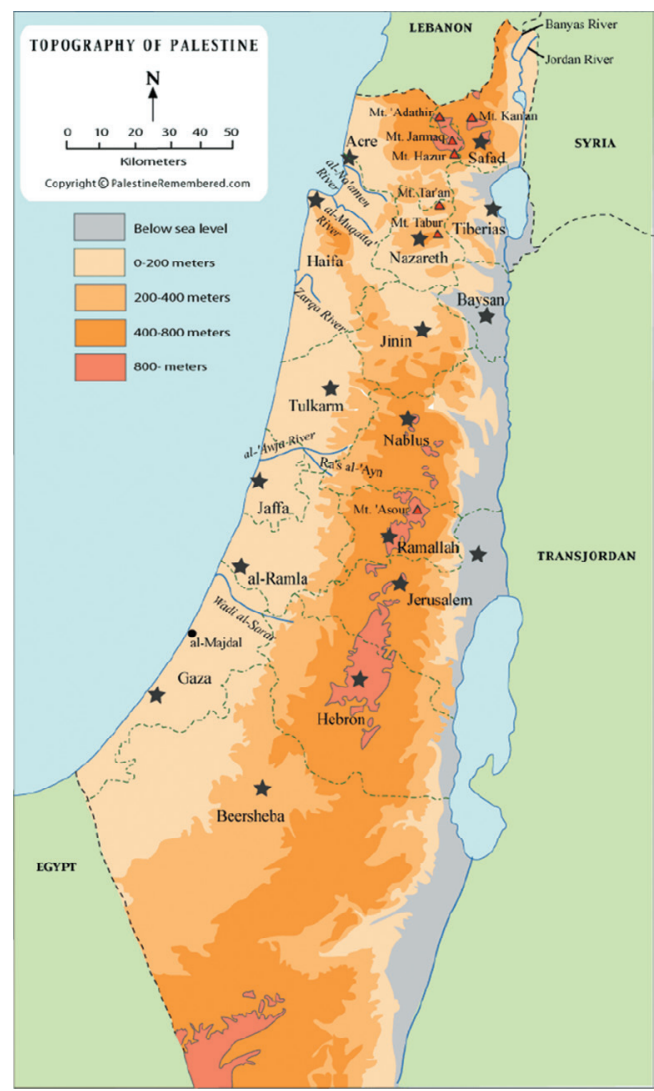

Figure 1: Map of Palestine (http://www.palestineremembered.com/Maps/New/Topography OfPalestine.gif).

As a result of Israeli incursion, restrictions have made it more difficult for Bedouins and residents of the Negev to reach Hebron city. Al-Dhahiriya functions as a major alternative market and service centre for the region. Moreover, the presence of a southern Israeli checkpoint used by the Palestinian workers has resulted in an overflow of traffic through the village.

\section{HISTORIC CENTRE}

The beauty and scale of Al-Dhahiriya's historic centre is a definite surprise to newcomers. It is relatively intact. Buildings and extended family courtyards are numerous and huge in scale. Reused large-cut stones are almost everywhere and a system of underground caves underneath homes and streets still exists (Fig. 2).

Settlement in Al-Dhahiriya was originally in the caves underneath the current historic centre. Although there are several archaeological remains that date back to Roman times, most of the buildings within the historic centre have the characteristics of Ottoman architecture in Palestine. This implies that during a certain point of history (most probably during the 16th and 17th centuries), families relocated from the caves and constructed their homes on top of them using local stone and recycled materials from surrounding archaeological sites and ruins. We can still see massive stone blocks in peasant houses with Roman and Crusader ornaments and decorations [2]. 


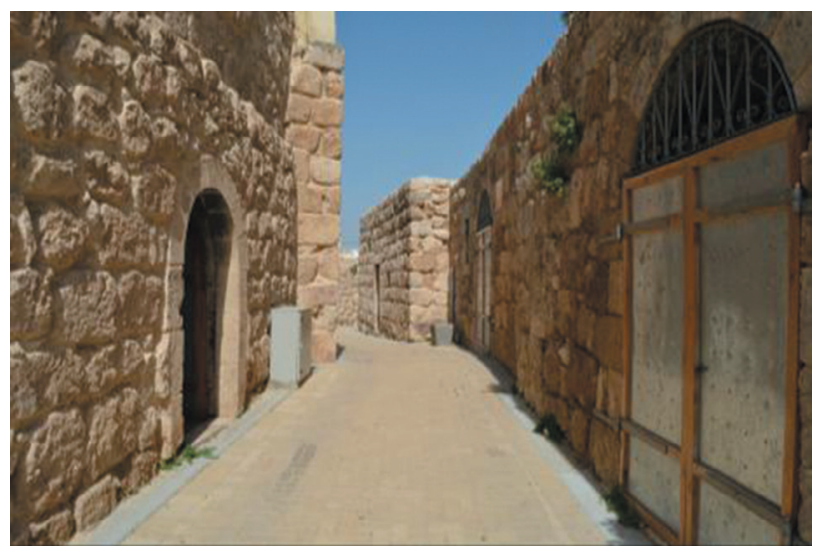

Figure 2: Historic centre (The Author).

The historic centre was deserted in the second half of the 20th century, presumably as a result of the rapid increase of population and subsequent construction of modern houses with new construction techniques. The area was not demolished to reuse the land for common buildings because of ownership fragmentation and property rights; yet at the same time, buildings were left to decay. The historic centre became home to only a few economically underprivileged families, and generally was only used as a passage to different parts of the village through the multiple alleys (including the old souk) linking the new commercial market street in the east to residential neighbourhoods in the west.

The old souk starts at al Harajeh plaza and continues south towards a populated residential neighbourhood, and extends to the Omari ancient mosque located at the southern edge of the historic centre. The old souk passes by local landmarks such as the Caesarea building (which is most likely an old caravanserai) and Hosh al Sabbar (courtyard).

\section{THE ELEMENTS CREATING THE URBAN FABRIC OF THE OLD CORE OF AL-DHAHIRIYA}

The old core has many buildings with different typologies referring to several eras. Some of the buildings date to the Roman era in addition to other buildings that were established in the Byzantine or Islamic era. This fact made it possible to study the urban and social history of this area since it has been inhabited for thousands of years.

However, the article focuses on examples of the historic buildings.

\subsection{The Roman Fort}

There are no sufficient data about the original size of the Roman Fort, locally known as Al Hisn, and all that remains are three barrel-vaulted rooms, an ancient water well and two cross-vaulted rooms that were added early in the 20th century. In coordination with the Department of Antiquities in the Hebron region, debris amounting to three meters in height was removed from the rooms, internal walls were torn down and new wooden floors were laid. With minimal intervention, the space was designed as an information centre for visitors and hosts a small collection of artefacts owned by the municipality. In 2014, the abandoned buildings north of al Khokha and up to the Roman Fort were safeguarded. Fifteen buildings 


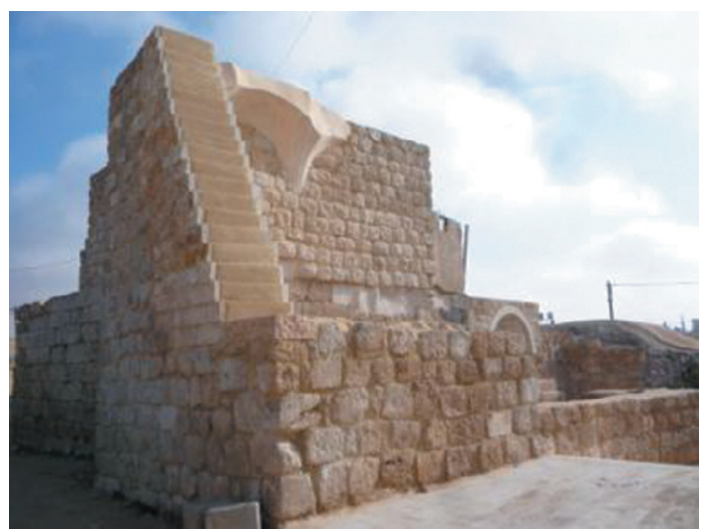

Figure 3: The Roman Fort (The Author).

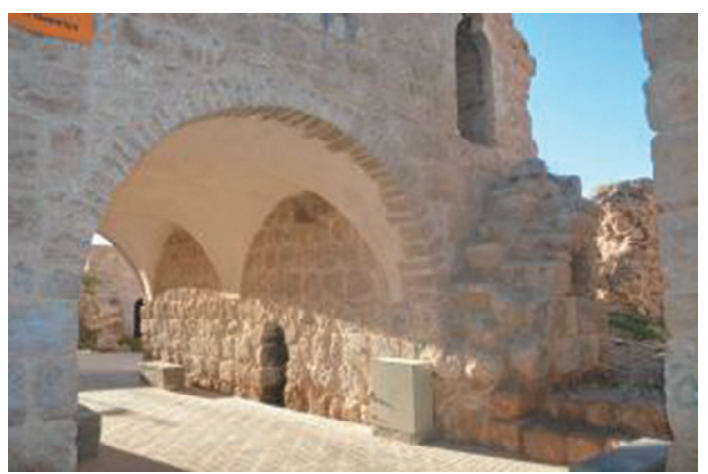

Figure 4: The vault (Arch. Sameeha Hashlamoon).

were restored and consolidated, and courtyards and streets were cleaned to prevent further deterioration. The realization of this work provided a walking path from the tourism information centre to the old souk, and onwards to the future guesthouse (Fig. 3).

\subsection{The vault (Al Qantara)}

The vault (Al Qantara) was found during the Ottoman era. It is also called Al Qaisariya and is located in the heart of the old core. The area of this building is about $37 \mathrm{~m}^{2}$ and its shape is a vault with a height of $3 \mathrm{~m}$. The vault is built on six arches where every arch is made of 44 stones; the building itself was a gathering place (Diwan). The Qantara is extensively used by the residents of the zone to move from the eastern to the western part of the village and vice versa. The building is a private-owned property for 'Mousa Al Sabbar' (Fig. 4).

The building has motifs and calligraphy in Greek. The building was established in different eras and it is believed that the motifs refer to the several courtyards located besides the building. 


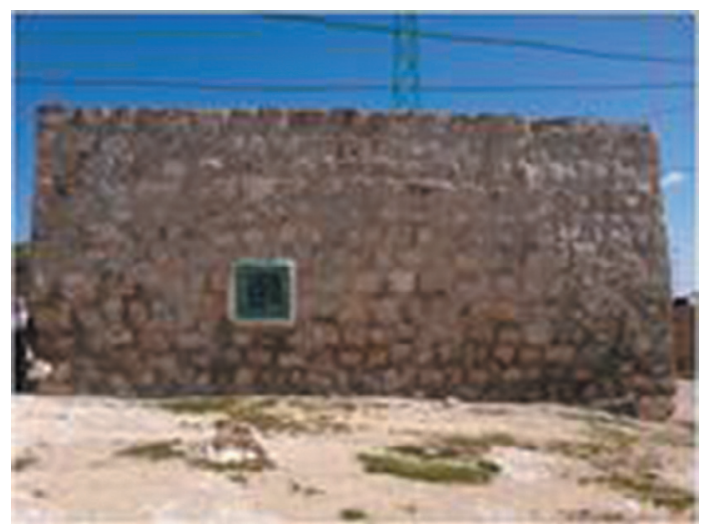

Figure 5: The Omari Mosque (The Author).

\subsection{The Omari Mosque}

The name of Omari Mosque refers to the second Khalifa 'Omar Ben Al-Khattab'. The mosque is similar in its features with the other mosques in the neighbouring villages. It was built using reused stone in addition to clay. Barrelled vaults were used in this mosque, and it is open to the north by a door on the eastern elevation; the mosque also has a window in the western side (Fig. 5).

\section{EXQUISITE FEATURES OF RESIDENTIAL ARCHITECTURE DURING ISLAMIC AGES IN AL-DHAHIRIYA}

Residential architecture in Al-Dhahiriya during and after Islamic ages is distinguished by real forms that resulted from conditions and requirements of life, stemming from thoughts derived from the Holy Quran and Sunna (prophetic traditions) that represent its conditions and environment. Residential architecture was not a forgery or imitation, and anyone who studies traditional architecture in Al-Dhahiriya can sense the struggle of architects (skilled builders) for development and sophistication. In addition, a person can watch and witness the gradual development in the use of structural techniques and the results of their continuous feeling and understanding of building values, in addition to witnessing the great ability of adaptation with conditions of different areas.

\subsection{Growth of architectural plan}

Traditional residences in old Al-Dhahiriya are a combination of development, experiences and experiments practised by Arab Muslim architects in search of fulfilment of their needs in accordance with prevailing climatic and environmental conditions. These traditional residences meet the psychological and thinking requirements stemming from the concept of a comprehensive Islamic way of life.

The common model of the old village in Al-Dhahiriya that prevailed in all houses in Palestinian villages and cities also continued developing along with the development of the family, that is, the horizontal projection of the houses and traditional dwellings in Al-Dhahiriya as a part of the study narrates the story of the family that lived in, in addition to the development that happened throughout the years. Whoever visits these houses in Al-Dhahiriya can realize 
that houses were developed through different stages. This can be seen through its different building stones, which indicates the difference in time periods of building the dwellings [3].

The architectural plan of the traditional houses implies that it started with one or more rooms and with the passage of time, there was a need for more rooms due to the increase in the number of family members, which means that it has been transferred from the core to the extended family. The factor that helps in this is the existence of the inner Fina' (patio) which made it possible to place stairs in the patio connecting the second floor, as a result building more rooms as needed.

\subsection{Exquisite features of architectural formations}

\subsubsection{Orientation}

Directing the buildings towards the inner Fina' indicates the nature of social life and climatic conditions, the outer space being replaced by the inner patios in order to accommodate the activities of residents. As a result, buildings in the old village appear contiguous with no spaces between them, and in case of not directing the building to the inside, the outer openings of the ground floors will be elevated and the windows will be covered by tasbils (mashrabiya) so as to maintain the privacy of residents of the dwelling.

\subsubsection{Decorations and formations}

Most traditional architectural buildings reflect the visual contrast in terms of dealing with outer structure and its inner details. The majority of buildings lack precise details in their outer appearance, whereas the inside has rich details and decorations that give spaces the elements of richness and vitality.

Among the elements are those used in the terraces, especially in the upper floors so as to maintain the privacy and climatic aspects. Pottery is mainly used for decorations due to its light weight and availability in the local environment.

\subsubsection{Treatment of climatic conditions}

Natural ventilation is of great importance. Architects realized the significance of natural ventilation for humans; therefore, they took ample care in utilizing natural ventilation due to the extreme temperatures in the summer. Convergence and clustering were important and basic matters in the dwellings of Al-Dhahiriya. Therefore, traditional solutions are the compact unity bound to the inside with an inner patio. The Fina' was an important element because it had several functions. The main function is creating flow of air that facilitates the natural ventilation. Moreover, it promotes natural lighting of the surrounding spaces.

\subsubsection{Organic setting in traditional architecture}

Traditional architecture was distinguished by organic setting and adaptation with environmental realities, in addition to the exquisite features of architecture in the city of Hebron such as the features of overlapping and harmony with its spatial conditions from geographical and topographical aspects. Therefore, environmental realities fit together organically from one side, and with climatic features from the other side whether on aspects of underlying details within the basic structure of the building themselves, or with annexed extensions.

The inner patio, the space factor common in most of the dwellings in Al-Dhahiriya, was not just a mere gap or emergency space; rather it was an organic breather around which the facilities of the building stabilize quietly. These patios, with all shadows, balconies, plants, running water and privacy, reflect a vital space for residents. In addition, using tasbils 


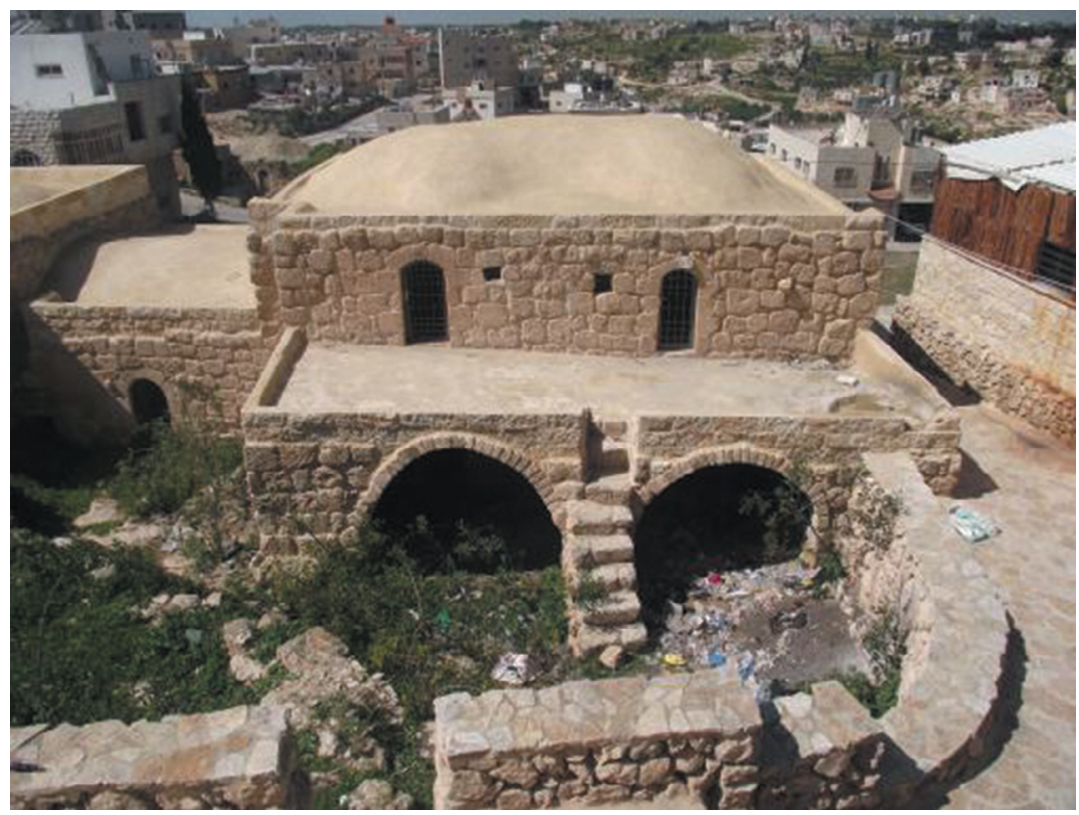

Figure 6: Organic settings of the dwelling (The Author).

(mashrabiyas) and wind catchers along with other architectural treatments undoubtedly indicate the great concern of Arab architects for dealing positively and realistically with environmental facts (Fig. 6).

\section{EXQUISITE FEATURES OF ARCHITECTURAL FORMATIONS IN AL-DHAHIRIYA DWELLINGS}

\subsection{Interior patios and suitability to local conditions}

Al-Fina' (courtyard - patio) is an open-sky court or the Sahn of the central building. Sometimes, the interior courtyard is called the Hosh (the house compound) which is a roofless space.

In their houses and dwellings, ancient Arabs and Muslims were concerned about the Fina' (the interior courtyard) and they relied on its construction to illuminate and ventilate the rooms, spaces and other places inside the building.

Sometimes, they took care of the provision of water, and the agricultural tubs have an effective function cooling the atmosphere inside the building and making it a vivid place full of life and movement. In addition, they were concerned about others' privacy in the neighbouring units.

Interior courtyards are considered as an environmental organizer and the lung through which the dwelling breathes since courtyards help air currents to move around to other parts of the dwelling. Patios have spread around in different shapes and sizes, often they represent a percentage of the length, width and height in the architectural plan [4]. 
The open courts in Al-Dhahiriya's dwellings constitute structural patterns with long-term social, environmental, religious and cultural heritage levels. It is considered not only as a mere inner space but also with other social practicable functions.

Interior patios help dwellings interact and be linked with the natural environment. Therefore, houses in Al-Dhahiriya had exterior facades with little openings which depended on open dwelling spaces to overlook the patios so as to receive light, ventilation and privacy. Open patios have achieved a number of fundamental functions to Al-Dhahiriya traditional dwellings; we summarize them in the following:

1. Providing dwellings with interior privacy that fulfils the requirements of Arab Islamic families by directing life to the inside around the patio, regulating the interior movement between the different parts of the dwelling. In addition, it is also used as a bioclimatic healer that regulates temperature and spreads air to all spaces in the dwelling.

2. Providing alternative natural environment rather than the noisy external environment that hurts optical privacy [5].

3. Patios accommodate activities of the family with all its different social and recreational patterns (gathering at night and children practising their games freely and safely) as well as household activities carried out by women inside the patios, such as washing, cooking, etc.

\section{EXTERNAL FACADES OF AL-DHAHIRIYA DWELLING AND SUITABILITY TO LOCAL CONDITIONS}

Architectural facades in Al-Dhahiriya are distinguished by exquisite architectural elements with harmonized aesthetic values that suit local environment despite its spontaneity most of the time. In addition, they were formed in accordance with the construction material available in the local environment (stones) with all its different types (arched stones, ceilings, ... etc.) and connected with a culture and values reflected in the old buildings despite the intervention of all cultures and norms.

Based on the analytical study carried out for the facades of residential buildings in the old city, the buildings contained openings and windows suitable for climatic and social conditions. The interior spaces were directed to the prevailing orientation of the winds and were consistent with the sun tilt angle during daylight hours, in addition to the creativity in the formation of the facade parts that allow the alternation of light and shade on them. The reason for the use of stone in buildings' facades is this material's constructive solidity, and also its good insulation properties against heat, humidity and rainfall. As for the treatment of the facades from the social aspect, entrances and windows did not face neighbours' entrances and windows, in addition using the broken access (indirect entrance) concept so that it preserves human privacy [6].

\section{BUILDING SYSTEMS AND MATERIAL TECHNOLOGIES AND SUITABILITY TO LOCAL CONDITIONS}

Generally, materials and construction systems of buildings in Palestinian architecture differ from the architecture in Al-Dhahiriya, in particular, due to the diversity of natural environment in Palestine and the availability and accessibility of local building materials. Among the most important materials used for buildings in the city are stones, whitewash and soil mixed with remnants of vaulted stones of all different sizes, pottery and many other materials suitable for building and having resistance against pressure and loads [7]. 
The mixture of stone and mud that is suitable for buildings, especially between the internal and external walls, is composed of many materials such as clay imported from Al-Khalil valley, sand stone and other organic materials. The mixture of mud, ash and lime strongly bonded in Aton (Liton) furnaces is a local construction system providing buildings with high resistance and durability. In addition, tree trunks were sometimes placed in sensitive areas such as hiding supports of the arched ceilings and doors to prevent them from cracking. Some building materials and systems worth mentioning are given in the next section.

\subsection{BUILDING MATERIALS USED IN THE OLD HOUSES}

\subsubsection{Building stones}

Since a long time, stones have been considered as a basic building material. Archaeological places and buildings have used these stones. It was used for building foundations with its three main types: the deep, the oolitic (or stony) and the surface foundations. Stones were also used as the structural, foundation and coating stones [8].

Stones were also used in exterior and interior bearing walls and in arches, roofs, stairs and doorways; in addition, small parts of the stones were used in stuffing and filling spaces (Fig. 7).

\subsubsection{Linking materials}

Pottery. One of the most important construction materials used in old houses is pottery. This material was used to reduce the weight of roofs; the material was also used in pottery parapet and the pottery powder was used as a linking material.

Lime. Lime is among the basic materials that are used in linking, bleaching and plastering in the old buildings. Lime is obtained from the calcareous stones available extensively in

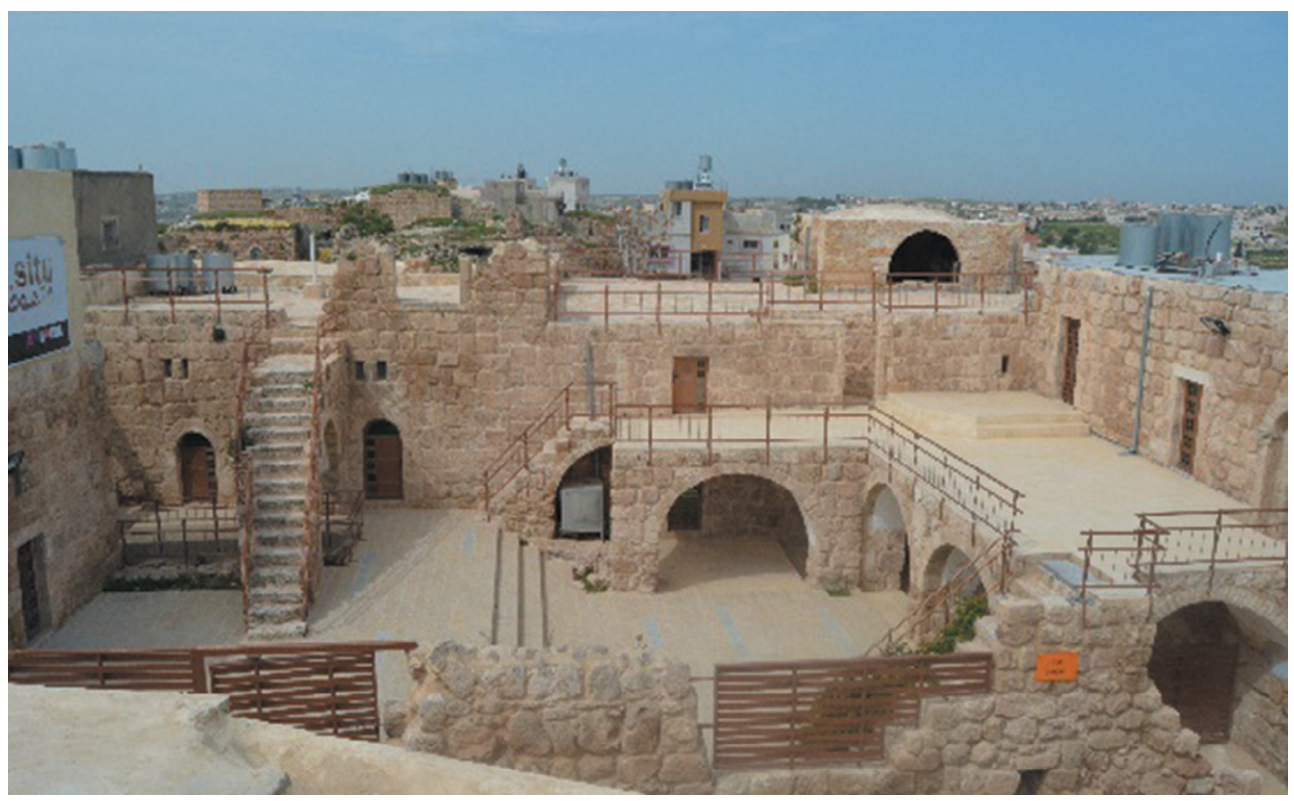

Figure 7: Old house - facades and building materials (Arch. Sameeha Hashlamoon). 
Palestine. It is produced by burning the stones in furnaces under temperatures that range between 1,000 and $1,800^{\circ} \mathrm{F}$. In addition, lime powder produced from breaking and sieving the pottery is also used for bleaching floors and roofs [9].

Ash. Ashes are the residues of burning vegetation and animals and it is used as a linking material together with calcareous lime since it gives great strength.

Steel. Since its production, steel has been used as a construction material. It is used to integrate linking materials with slabs. In addition, it is used for protecting doors, windows and main gates of the entrances, so it is not used very much in the old houses.

Wood. Wood is known as a basic building material and a helping material in the different carpentry works such as doors and windows. Wood was also used as partition walls and as formworks for the ceilings and arches.

Zibar. It is a residue of oil extracted from olive trees. It is used in foundations and floors because of its impermeability properties.

The Fibre (Leafah). Leafah is a material taken from palm trees and other special trees called the Leafah trees. The Leafah was used as insulation and anti-cracking treatment material, and enhancer of soil features in the formworks and as linking wood pieces for formworks.

\section{REFERENCES}

[1] Sherlock, R., Palestinian in bid to revive the old city, Hebron residents put on traditional food festival, 2010.

[2] Hakim, B.S., Arabic-Islamic Cities - Building and Planning Principles, KPI Limited: London, 1986.

[3] Khasawneh, D., Memories Engraved in Stone Palestinian Urban Mansions, Riwaq Publications: Ramallah, 2001.

[4] Jubeh, N., Al-khalil Al-kadema Sehro Madena Wa 'Amara Tarkhyah Old- Hebron, a City Misty and Historical Architecture, Hebron Rehabilitation Committee, Hebron, 2008.

[5] Rahman, M. Al-Khalil, The Encyclopedia of Islam New Edition, eds E. Van Donzel, B. Lewis \& Ch., E.J. Pellat, BRILL: Leiden, (IV), 1978.

[6] Kark, R., The introduction of modern technology into the Holy Land 1800-1914 CE. The Archaeology of Society in the Holy Land, ed. T.E. Levy, Continuum International Publishing Group: New York, 1995.

[7] Vitullo, A., People tide to place: strengthening cultural identity in Hebron's old city. Journal of Palestine Studies, 33(1), pp. 68-83, 2003. DOI: 10.1525/jps.2003.33.1.68.

[8] Hebron Rehabilitation Committee, RAWIQ, Swedish International Development Cooperation Agency (SIDA). Survey of the Traditional Town Neighborhoods and Buildings, HRC, Hebron, Palestine, 2011.

[9] Al Khalili, M., History of Jerusalem and Al-khalil, ed. M. Al Bakhit republished in 2004, Al-Furqan Islamic Heritage Foundation: London, 1734. 